\title{
Ketersediaan dan Serapan Ca Pada Kacang Tanah di Tanah Alfisols yang Diberi Abu Vulkanik Kelud dan Pupuk Kandang
}

\author{
Suntoro2), Jauhari Syamsiyah²), Widyas Rahina1)
}

\begin{abstract}
Volcanic ash actually need agent like an organic matter to mineralized. The study aims is to determine the effect of volcanic ash of Kelud and manure on the availability of calcium in Alfisols, the absorbent of calsium and their status for peanuts growth. This is greenhouse experiment arranged in factorial completely randomized design with single treatment. The result have been analyzed with analysis of variance by $\mathrm{F}$ test at $5 \%$ and the average comparison test using DMRT at $5 \%$ than will continued with Pearson Corelation test for analyzing the relation of intervariable. The results showed that volcanic ash of Kelud eruption and manure treatment significantly on leaves, chlorophyll, nodules, weight of wet crop stover, $\mathrm{pH}, \mathrm{CEC}, \mathrm{Ca}$-total and $\mathrm{Ca}$ plant tissue but no significant on height of peanuts, stover dry weight, exchangable $\mathrm{Ca}$ and $\mathrm{Ca}$ uptake.Volcanic ash of Kelud and manure are better used as ameliorant than as a planting media.
\end{abstract}

Keywords : alfisols, calsium, manure, peanut, volcanis ash

\section{PENDAHULUAN}

Gunung Kelud mengalami erupsi terakhir pada tahun 2014 dan membawa dampak sangat luas salah satunya adalah sebaran abu vulkanik hingga mencapai hampir seluruh wilayah kota Solo dan Yogyakarta sehingga mengakibatkan kedua kota tersebut tertutup abu vulkanik yang cukup pekat, bahkan melumpuhkan 6 bandara internasional dan 100.000 orang harus dievakuasi. Dampak abu vulkanik juga dirasakan di sektor pertanian, abu vulkanik yang menutupi sebagian besar lahan pertanian menyebabkan tanah memadat serta membawa dampak secara langsung terhadap pertumbuhan tanaman yaitu mengurangi fotosintesis hingga 90\% karena terjadi penimbunan abu dipermukaan daun (Cook et al.1981). Disamping itu abu vulkanik berdampak terhadap kondisi lahan pertanian yaitu abu vulkanik akan mengurangi infiltrasi tanah, berakibat pada meningkatnya run off, pemadatan dan erosi.

Dampak positif juga bisa diberikan oleh abu vulkanik bagi tanah, antara lain yaitu dapat memperkaya dan meremajakan tanah sehingga meningkatkan kesuburan tanah dan pertumbuhan tanaman (Andreita 2011). Abu vulkanik mengandung mineral yang dibutuhkan oleh tanah dan tanaman dengan komposisi total unsur tertinggi yaitu $\mathrm{Ca}, \mathrm{Na}$, $\mathrm{K}$ dan $\mathrm{Mg}$, unsur

\footnotetext{
1)Lecturer Staff of Study Program of Agrotechnology, Faculty of Agriculture, Sebelas Maret University (UNS) on Surakarta.

2) Undergraduate Student of Study Program of Agrotechnology, Faculty of Agriculture, Sebelas Maret University (UNS) on Surakarta.

Contact Author: dyazzzchristy2013@gmail.com
}

makro berupa $P$ dan $S$ serta unsur mikro seperti $\mathrm{Fe}, \mathrm{Mn}, \mathrm{Zn}$ dan $\mathrm{Cu}$ (Anda dan Wahdini 2010).

Kandungan mineral abu vulaknik tidak tersedia untuk tanaman apabila diaplikasikan dalam jangka pendek setelah letusan dan baru bisa dimanfaatkan kurang lebih 10 tahun setelah terjadinya letusan gunung sehingga perlu dibantu dengan pemupukan untuk memelihara kesuburan tanah. Apabila penambahan abu vulkanik dilakukan dalam jangka panjang maka dapat menjadi cadangan mineral bagi tanah (Rostaman et al. 2012).

Tanah Alfisols merupakan salah satu tanah yang banyak dijumpai di Indonesia (Wijanarko et al. 2007). Tanah ini juga memiliki potensi untuk budidaya tanaman kacang tanah, namun terdapat beberapa kendala pada tanah ini salah satunya adalah hilangnya lapisan atas tanah karena tingkat erosi yang tinggi yang berkisar antara $0.42-524$ ton/ha pada tanah Alfisols yang ditanami jagung dan kacang tunggak akibat sistem pengelolaan tanah yang berbeda ( $R$ Lal 2003). Akibat erosi tersebut maka kandungan unsur hara dalam tanah dapat mengalami penurunan.

Disisi lain, permasalahan utama dalam penyediaan $\mathrm{Ca}$ bagi tanaman adalah pada kebanyakan tanah kandungan unsur tersebut rendah dan tidak semua kalsium yang diberikan dapat segera tersedia bagi tanaman. Pada beberapa tanah yang memiliki sifat masam, keberadaan alumunium justru menambah terhambatnya serapan kalsium dengan cara memblokir saluran $\mathrm{Ca}^{2+}$ ke membran plasma. Dengan demikian material abu vulkanik yang masih belum banyak dimanfaatkan merupakan suatu hal yang dapat diteliti lebih lanjut 
khususnya tentang kelayakan penggunaan abu vulkanik tersebut untuk budidaya tanaman.

\section{BAHAN DAN METODE}

Penelitian merupakan percobaan rumah kaca dengan menggunakan tanah Alfisols dari lahan percobaan Jumantono yang diambil secara komposit dan dipindahkan ke Rumah Kaca C, Fakultas Pertanian, Universitas Sebelas Maret Surakarta Jawa Tengah. Penelitian dilakukan bulan September sampai Desember 2015. Bahan abu vulkanik gunung Kelud diperoleh dari abu vulkanik yang jatuh di wilayah Solo dan telah dikumpulkan pasca letusan Gunung Kelud tahun 2014 silam. Pupuk kandang didapat dari rumah kompos Fakultas Pertanian UNS dan pada kondisi kering udara dicampur dengan $6 \mathrm{~kg}$ tanah lapisan atas kering udara (ukuran $<2 \mathrm{~mm}$ ) serta abu sesuai perlakuan kemudian dimasukan ke dalam polibag dengan ukuran $35 \times 35 \mathrm{~cm}$.

Penelitian menggunakan Rancangan Acak Lengkap (RAL) dengan perlakuan sebagai berikut: abu vulkanik $6 \mathrm{~kg}$, tanah $6 \mathrm{~kg}$, tanah + abu vulkanik $1 \mathrm{~kg}$, tanah + abu vulkanik $2 \mathrm{~kg}$, tanah + abu vulkanik $3 \mathrm{~kg}$, tanah + pupuk kandang 12.5 gram, tanah + abu vulkanik $1 \mathrm{~kg}+$ pupuk kandang, tanah + abu vulkanik $2 \mathrm{~kg}+$ pupuk kandang, tanah + abu vulkanik $3 \mathrm{~kg}+$ pupuk kandang. Setiap perlakuan diulang 4 kali sehingga didapatkan 36 satuan percobaan.

Panen dilakukan pada saat pertumbuhan tanaman kacang tanah mencapai pertumbuhan vegetatif maksimum (60 hari setelah tanam). Pengamatan yang dilakukan meliputi; tinggi tanaman, jumlah daun, kadar klorofil, bintil akar,berat biomassa basah, berat biomasa kering (kering oven $60^{\circ} \mathrm{C}$ selama 48 jam) untuk tajuk dan akar. Kandungan $\mathrm{Ca}$ dalam biomasa tanaman kacang tanah ditetapkan dengan destruksi basah menggunakan $\mathrm{HNO} 3$ 65\% dan $\mathrm{HClO}_{4} \quad 70 \%$, dan analisis tanah setelah percobaan meliputi $\mathrm{pH}$ dengan metode elektrometri (perbandingan tanah dan air adalah 1: 2.5), KTK (ekstrak NH4-OAc pH 7,0), Ca-total (pengabuan basah menggunakan HNO3 65\% dan $\mathrm{HClO} 4$ 70\%) dan Ca-tersedia (ekstrak NH4OAc pH 7,0), dengan Atomic Absoption Spectrophotometer (AAS) (Kim 1996; Puslitanak 1998). Data hasil pengamatan dianalisis dengan analisis sidik ragam pada taraf $95 \%$. Bila ada pengaruh yang nyata dilakukan pengujian DMRT (Duncan's Multiple Range Test) taraf 95\%.

\section{HASIL DAN PEMBAHASAN}

\section{Kandungan Ca Total}

Tidak semua kalsium yang ada dalam tanah berada dalam bentuk yang dapat diserap oleh tanaman, oleh karenanya konsentrasi kalsium tanah yang tinggi tidak selalu sejalan dengan serapan kalsiumnya. Konsentrasi $\mathrm{Ca}^{2+}$ dalam tanah dapat menurun akibat adanya pengendapan asam sehingga mempengaruhi hasil panen secara langsung (Berker dan Pilbean 2007). Keberadaan kalsium sering dikaitkan dengan kemasaman tanah karena mengandung kation yang dapat mengurangi efek kemasaman baik dalam tanah maupun dalam tanaman.

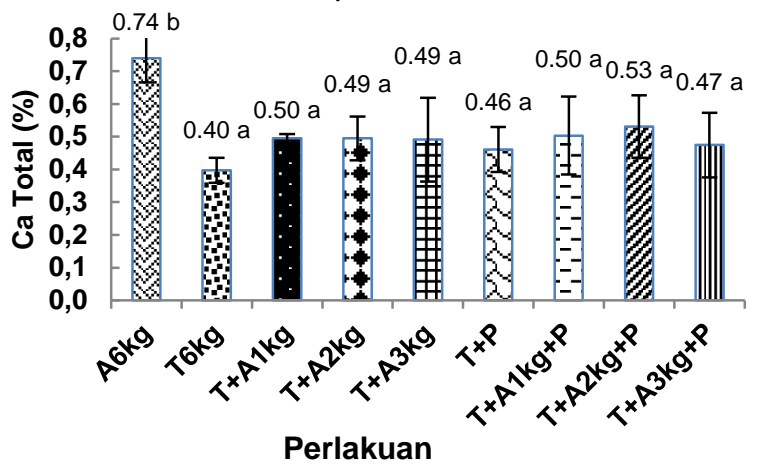

Keterangan: $\mathrm{A}=$ Abu vulkanik Kelud, $\mathrm{T}=$ Tanah Alfisol, $\mathrm{P}=$ Pupuk Kandang

Gambar 1. Pengaruh Pemberian Abu Vulkanik Kelud dan Pupuk Kandang terhadap Ca Total Tanah

Hasil analisis ragam menunjukkan bahwa pemberian abu vulkanik Kelud dan pupuk kandang dapat meningkatkan kandungan $\mathrm{Ca}$ total tanah. Hal ini dikarenakan abu vulkanik mengandung unsur kalsium yang cukup tinggi (Anda dan Wahdini 2010) begitupun dengan pupuk kandang (Priyono dan Sarwono 2015). Gambar 1. menunjukkan bahwa pemberian abu vulkanik Kelud dan pupuk kandang tiap perlakuan berbeda nyata dengan abu vulkanik 6 kg. Tanah yang diberi abu vulkanik dan pupuk kandang mengalami peningkatan nilai $\mathrm{Ca}$ total tanah lebih tinggi dibandingkan dengan tanah yang hanya diberi abu vulkanik saja.

Keberadaan kalsium sering dikaitkan dengan kemasaman tanah karena mengandung kation yang dapat mengurangi efek kemasaman. Abu vulkanik $6 \mathrm{~kg}$ memiliki nilai $\mathrm{pH}$ tertinggi (6.58), sedangkan tanah $6 \mathrm{~kg}$ memiliki nilai $\mathrm{pH}$ terendah (5.7) dibanding semua perlakuan. Hal tersebut menjadi salah satu alasan mengapa kalsium total pada tanah $6 \mathrm{~kg}$ memiliki nilai yang rendah. Hal ini didukung oleh pernyataan Soemarno (2010), kalsium tanah akan menurun apabila $\mathrm{pH}$ berada dibawah 7 maupun diatas 8.5 dan akan meningkat pada kisaran pH 7.0 - 8.5. Selain tingkat kemasaman, tanah $6 \mathrm{~kg}$ memiliki KTK terendah yang dapat menjadi penyebab rendahnya nilai kalsium total tanah pada perlakuan ini. Hal ini didukung oleh pernyataan Barber (1984) yang menyatakan bahwa semakin tinggi KTK tanah maka umumnya $\mathrm{Ca}$ tanah juga semakin tinggi juga begitupun sebaliknya. 


\section{Ca tersedia}

$\mathrm{Ca}^{2+}$ merupakan bentuk kalsium yang biasa diserap oleh tanaman atau bentuk kalsium yang dapat ditukarkan. Kalsium dapat dipertukarkan atau diserap oleh akar tanaman baik melalui intersepsi akar ataupun aliran massa. Rata-rata $\mathrm{Ca}$ tersedia tiap perlakuan ditunjukkan oleh Tabel 1.

Tabel 1. Rata-rata Ca Tersedia Tanah

\begin{tabular}{lcl} 
Perlakuan & $\begin{array}{c}\text { Ca Tersedia } \\
(\mathrm{cmol}(+) / \mathrm{kg})\end{array}$ & \\
\hline A6kg & $11.38 \mathrm{a}$ & Keterangan: \\
T6kg & $8.46 \mathrm{a}$ & $\begin{array}{l}\text { A: Abu vulkanik Kelud } \\
\text { T: Tanah Alfisol }\end{array}$ \\
T+A1kg & $8.48 \mathrm{a}$ & P: Pupuk kandang \\
T+A2kg & $9.61 \mathrm{a}$ & \\
T+A3kg & $10.68 \mathrm{a}$ & \\
T+P & $10.40 \mathrm{a}$ & \\
T+A1kg+P & $8.85 \mathrm{a}$ & \\
T+A2kg+P & $10.57 \mathrm{a}$ & \\
T+A3kg+P & $9.25 \mathrm{a}$ & \\
\hline
\end{tabular}

Abu vulkanik $6 \mathrm{~kg}$ memiliki nilai $\mathrm{Ca}$ tersedia paling tinggi dibandingkan semua perlakuan yang mungkin dikarenakan nilai $\mathrm{Ca}$ total abu vulkanik 6 kg juga paling tinggi. Walaupun terdapat peningkatan $\mathrm{Ca}$ tersedia tanah setelah pemberian abu vulkanik dan pupuk kandang, namun hal tersebut belum bisa memberikan pengaruh yang nyata terhadap $\mathrm{Ca}$ tersedia tanah. Hal ini mungkin dikarenakan unsur-unsur yang terdapat pada abu vulkanik masih berada dalam bentuk yang belum tersedia bagi tanaman sehingga perlu waktu untuk mendekomposisi unsur tersebut supaya bisa berada dalam bentuk tersedia bagi tanaman (Cook et al. 1981).

\section{Ca Jaringan}

Kalsium dalam daun sering mengendap dalam bentuk kristal kalsium oksalat. Umur tanaman juga berpengaruh terhadap kadar ion Ca. Semakin tua umur tanaman, maka semakin tinggi kadar Ca organ tanaman tersebut. Dalam sel tanaman, ion Ca terdapat paling banyak pada permukaan luar sitoplasma dan lamela tengah (Rosmarkam dan Yuwono 2002).

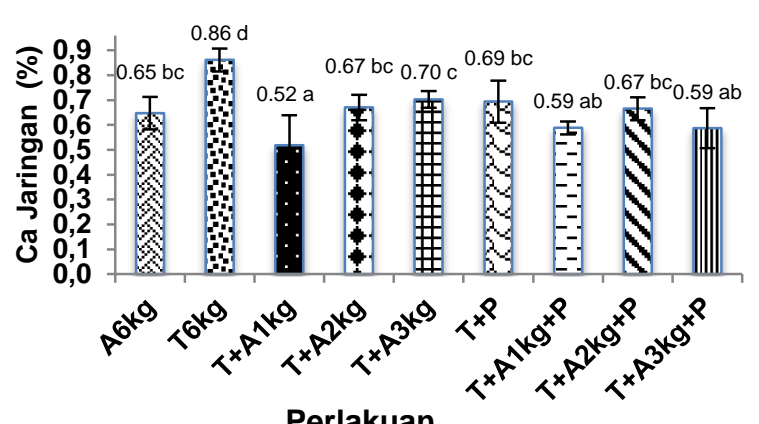

Keterangan: $\mathrm{A}=$ Abu vulkanik Kelud, $\mathrm{T}=$ Tanah Alfisol, $\mathrm{P}=$ Pupuk Kandang

Gambar 2. Pengaruh Pemberian Abu Vulkanik Kelud dan Pupuk Kandang terhadap Ca Jaringan Tanaman Kacang Tanah saat Fase Vegetatif Maksimum

Hasil analisis ragam menunjukkan bahwa pemberian abu vulkanik Kelud dan pupuk kandang memberikan pengaruh yang nyata terhadap $\mathrm{Ca}$ jaringan tanaman. Gambar 2. menunjukkan bahwa pemberian abu vulkanik 6 $\mathrm{kg}$ memberikan hasil yang berbeda nyata dengan tanah $6 \mathrm{~kg}$ dan tanah + abu $1 \mathrm{~kg}$. Tanah + abu vulkanik $1 \mathrm{~kg}$ juga berbeda nyata dengan tanah + abu $2 \mathrm{~kg}$, tanah + abu $3 \mathrm{~kg}$, tanah + pupuk kandang dan tanah + abu $2 \mathrm{~kg}+$ pupuk kandang. Tanah $6 \mathrm{~kg}$ memiliki $\mathrm{Ca}$ jaringan yang berbeda nyata dengan semua perlakuan.

Jordan et al. (2016) kalsium bergerak ke dari akar menuju ke bagian atas tanaman namun tidak akan kembali ke bagian bawah lagi. Hasil $\mathrm{Ca}$ jaringan tanaman yang diperoleh pada penelitian kali ini lebih rendah daripada kebutuhan $\mathrm{Ca}$ jaringan tanaman kacang tanah pada umumnya yaitu $1.25 \%-2.0 \%$ (Reuter and Robinson 1986). Hal ini mungkin dikarenakan perakaran tanaman yang kurang berkembang dan menyebabkan unsur hara kalsium yang masuk ke dalam tubuh tanaman melalui intersepsi akar menjadi terhambat. Selain itu penambahan abu vulkanik menyebabkan tekstur tanah menjadi keras dan sukar untuk menyerap air. Hal ini menyebabkan jumlah air yang dapat diserap dan ditranspirasikan tanaman berkurang. Kondisi suhu di rumah kaca yang relatif tinggi menyebabkan proses transpirasi juga berjalan cepat, namun karena air yang dapat ditranspirasikan sedikit, maka konsentrasi kalsium yang ikut larut terbawa oleh air transpirasi melalui aliran massa juga berkurang, sehingga konsentrasi kalsium dalam jaringan tanaman ikut berkurang menyesuaikan konsentrasi kalsium yang larut dalam air transpirasi. Clarkson (1984) menambahkan bahwa pendistribusian kalsium ke jaringan tanaman akan meningkat ketika ion $\mathrm{Ca}^{2+}$ di xilem rendah sedangkan laju transpirasi tinggi. 


\section{Serapan Ca}

Serapan Ca merupakan hasil kali antara berat brangkasan kering tanaman dengan $\mathrm{Ca}$ jaringan tanaman. Serapan $\mathrm{Ca}$ sangat dipengaruhi oleh berat brangkasan kering tanaman dan juga Ca jaringan tanaman. Apabila tanaman memiliki berat brangkasan kering yang tinggi namun nilai $\mathrm{Ca}$ jaringan rendah maka nilai serapan $\mathrm{Ca}$ akan turun begitu juga sebaliknya. Apabila nilai brangkasan kering dan $\mathrm{Ca}$ jaringan tanaman tinggi, maka nilai serapan $\mathrm{Ca}$ tanaman juga akan tinggi begitu juga sebaliknya. Hasil analisis ragam menunjukkan bahwa pemberian abu vulkanik Kelud dan pupuk kandang belum bisa secara nyata meningkatkan serapan $\mathrm{Ca}$ tanaman. Rata-rata serapan $\mathrm{Ca}$ tanaman disajikan pada Tabel 2.

Tabel 2. Rata-rata Serapan Ca Tanaman

\begin{tabular}{|c|c|c|}
\hline Perlakuan & $\begin{array}{l}\text { Serapan Ca } \\
\text { (g/tanaman) }\end{array}$ & \multirow{10}{*}{$\begin{array}{l}\text { Keterangan: } \\
\text { A: Abu vulkanik Kelud } \\
\text { T: Tanah Alfisol } \\
\text { P: Pupuk kandang }\end{array}$} \\
\hline A6kg & $1.38 a$ & \\
\hline T6kg & $2.84 a$ & \\
\hline $\mathrm{T}+\mathrm{A} 1 \mathrm{~kg}$ & $2.29 a$ & \\
\hline $\mathrm{T}+\mathrm{A} 2 \mathrm{~kg}$ & $3.02 a$ & \\
\hline $\mathrm{T}+\mathrm{A} 3 \mathrm{~kg}$ & $2.67 a$ & \\
\hline $\mathrm{T}+\mathrm{P}$ & $3.25 a$ & \\
\hline $\mathrm{T}+\mathrm{A} 1 \mathrm{~kg}+\mathrm{P}$ & $2.82 a$ & \\
\hline $\mathrm{T}+\mathrm{A} 2 \mathrm{~kg}+\mathrm{P}$ & $2.56 a$ & \\
\hline $\mathrm{T}+\mathrm{A} 3 \mathrm{~kg}+\mathrm{P}$ & $2.34 a$ & \\
\hline
\end{tabular}

Pemberian abu vulkanik Kelud dan pupuk kandang yang tidak berpengaruh terhadap serapan $\mathrm{Ca}$ mungkin dikarenakan kebutuhan kalsium jaringan tanaman belum dapat terpenuhi (rendah). Selain itu faktor lain yang mungkin menjadi penyebab adalah perakaran tanaman yang kurang bisa berkembang karena media yang memadat atau mengeras. Menurut Keisling dan Walker (2008), rendahnya konsentrasi Ca dalam tanah khususnya di sekitar perakaran tanaman menjadi salah satu faktor yang menyebabkan berkurangnya serapan $\mathrm{Ca}$ oleh tanaman kacang tanah. Winarso (2005) menambahkan bahwa kemampuan tanaman menyerap kalsium terbatas dikarenakan kalsium hanya dapat diserap oleh ujung-ujung akar muda.

\section{Jumlah Daun}

Jumlah dan ukuran daun dipengaruhi oleh genotip dan faktor lingkungan (tanah, air, cahaya dan unsur hara) sekitar tanaman tumbuh (Ohorella 2011). Banyaknya daun akan mempengaruhi jumlah klorofil yang berperan dalam proses fotosintesis dengan menyerap dan mengubah energi cahaya menjadi energi kimia (Li et al. 2006). Jumlah daun dengan klorofil yang banyak akan meningkatkan asimilat yang dihasilkan yang pada akhirnya berpengaruh pada pembentukan daun dan organ tanaman yang lain.

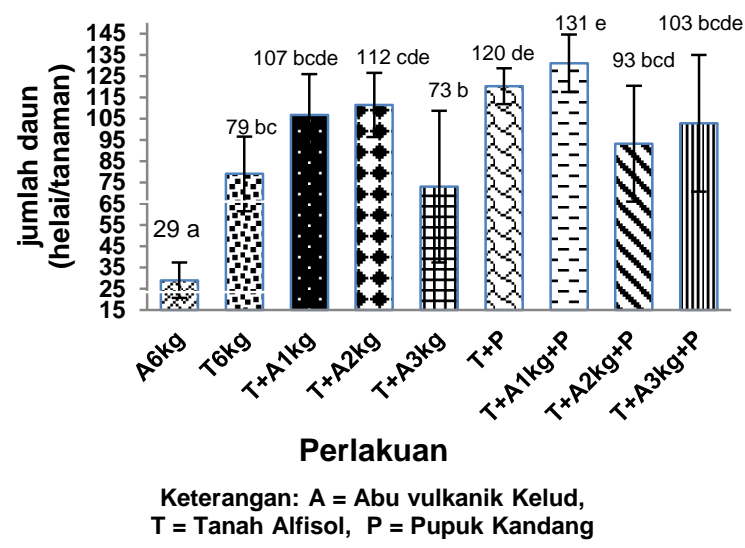

Gambar 3. Pengaruh Pemberian Abu Vulakanik Kelud dan Pupuk Kandang terhadap Jumlah Daun Tanaman Kacang Tanah Saat Fase Vegetatif Maksimum

Perlakuan abu vulkanik $6 \mathrm{~kg}$ dimana abu vulknik diberikan sebagai media tanam memiliki jumlah daun paling sedikit diantara semua perlakuan. Hal tersebut membuktikan bahwa pemberian abu vulkanik sebagai media tanam ternyata dapat menumbuhkan benih kacang tanah, namun tidak dapat memberikan hasil yang baik terhadap pertumbuhan jumlah daun tanaman. Hasil analisis ragam menunjukkan pemberian abu vulkanik Kelud dan pupuk kandang sebagai bahan pembenah tanah dapat memberikan pengaruh yang nyata terhadap jumlah daun tanaman. Gambar 3. menunjukkan bahwa tanah + pupuk kandang dan tanah + abu vulkanik $1 \mathrm{~kg}+$ pupuk kandang memiliki hasil yang berbeda nyata dengan abu vulkanik $6 \mathrm{~kg}$ dan tanah $6 \mathrm{~kg}$.

Hasil uji korelasi antara jumlah daun dengan tinggi tanaman menunjukkan keduanya saling berhubungan $(r=0.434)$. Hasil uji korelasi menunjukan bahwa jumlah daun juga saling berhubungan positif dengan kadar klorofil $(r=0.606), \quad p H \quad(r=0.675)$ serta serapan $\mathrm{Ca}$ $(r=0.540)$. Menurut Sitompul dan Guritno (1995), tanaman yang memiliki daun banyak akan lebih cepat tumbuh (termasuk menjadi lebih tinggi) karena kemampuan menghasilkan fotosintat yang lebih tinggi daripada tanaman dengan jumlah daun yang lebih sedikit dimana fotosintat dihasilkan dari proses fotosintesis yang berkaitan erat dengan keberadaan klorofil tanaman. Fotosintat yang semakin banyak ini akan berpengaruh terhadap berat brangkasan basah dan berat brangkasan kering tanaman yang akan semakin besar nilainya. Brangkasan kering yang akan berpengaruh terhadap serapan $\mathrm{Ca}$ dimana 
nilai brangkasan kering yang makin besar akan diikuti oleh nilai serapan $\mathrm{Ca}$ yang makin besar terlebih apabila didukung oleh nilai $\mathrm{Ca}$ jaringan yang besar juga.

\section{Berat Brangkasan Basah Tanaman}

Berat basah tanaman merupakan total berat tanaman yang menunjukkan hasil aktivitas metabolik tanaman tersebut (Salisbury dan Ross 1995). Rata-rata brangkasan basah tanaman kacang tanah tiap perlakuan ditunjukkan Gambar 4.

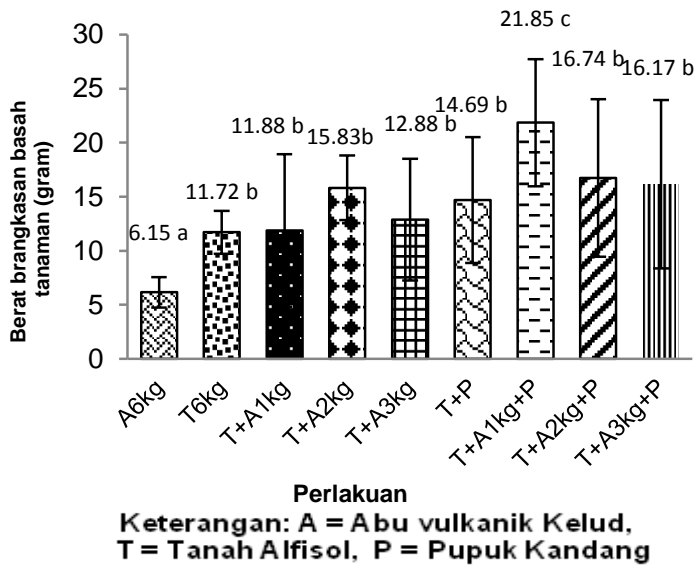

Gambar 4. Pengaruh Pemberian Abu Vulakanik Kelud dan Pupuk Kandang terhadap Berat Brangkasan Basah Kacang Tanah Saat Fase Vegetatif Maksimum

Hasil analisis ragam menunjukkan bahwa penambahan abu vulkanik Kelud dan pupuk kandang berpengaruh terhadap berat brangkasan basah tanaman. Pemberian abu vulakanik dan pupuk kandang yang semakin banyak berbeda nyata dengan abu vulkanik $6 \mathrm{~kg}$ dan tanah + abu vulkanik $1 \mathrm{~kg}+$ pupuk kandang, hal tersebut mungkin dikarenakan tanaman relatif tinggi didukung jumlah daun dan kandungan klorofil tanaman juga tinggi. Menurut Sitompul dan Guritno (1995), salah satu faktor yang mempengaruhi berat brangkasan basah tanaman adalah jumlah dan ukuran tajuk tanaman, semakin banyak jumlah daun dan semakin tinggi tanaman maka berat brangkasan basah tanaman juga akan semakin besar.Hal tersebut juga didukung dengan uji korelasi dimana brangkasan basah memiliki hubungan dengan tinggi tanaman $(r=0.358)$, jumlah daun $(r=0.694)$, kandungan klorofil $(r=0.513)$ dan bintil akar $(r=0.467)$.

Hasil korelasi menunjukkan bahwa terdapat hubungan antara brangkasan basah tanaman dengan serapan $\mathrm{Ca}(r=0.731)$. Salah satu peran kalsium adalah berguna dalam pembentukan dan pembelahan sel. Apabila serapan Ca berkurang maka pembentukan akar muda menjadi terhambat sehingga pasokan air dan unsur hara ke dalam tubuh tanaman juga akan berkurang. Air digunakan sebagai sumber elektron dan zat pelarut yang membawa unsur hara masuk kedalam tubuh tanaman serta mentranslokasikan fotosintat hasil fotosintesis ke bagian tanaman yang lain. Apabila jumlah air yang diserap tanaman berkurang, maka konsentrasi unsur hara yang terlarut di dalamnya bisa ikut berkurang. Hal ini menyebabkan pertumbuhan tanaman menjadi terhambat tidak terkecuali berat brangkasan basah tanaman.

\section{Berat Brangkasan Kering Tanaman}

Berat kering merupakan hasil penimbunan bersih asimilasi $\mathrm{CO}_{2}$ (Larcher 1975). Semakin tinggi nilai brangkasan kering tanaman maka tanaman tersebut semakin efisien dalam melakukan proses fotosintesis dan menghasilkan fotosintat. Selain itu, tingginya brangkasan kering juga berhubungan dengan tingginya serapan unsur hara (termasuk kalsium) oleh tanaman yang akan digunakan dalam pembentukan senyawa kompleks yang membentuk bagianbagian tubuh tanaman seperti akar, batang dan daun. Rata-rata brangkasan kering tanaman kacang tanah tiap perlakuan ditunjukkan Tabel 3.

Tabel 3. Rata-rata Brangkasan Kering Tanaman

\begin{tabular}{lcl}
\hline Perlakuan & $\begin{array}{c}\text { Brangkasan Kering } \\
\text { (gram) }\end{array}$ \\
\hline A6 kg & $2.13 \mathrm{a}$ & Keterangan: \\
T6 kg & $3.3 \mathrm{a}$ & A= Abu vulkanik Kelud \\
$\mathrm{T}+\mathrm{A} 1 \mathrm{~kg}$ & $4.4 \mathrm{a}$ & $\mathrm{T}=$ Tanah Alfisols \\
$\mathrm{T}+\mathrm{A} 2 \mathrm{~kg}$ & $4.51 \mathrm{a}$ & $\mathrm{P}=$ Pupuk kandang \\
$\mathrm{T}+\mathrm{A} 3 \mathrm{~kg}$ & $3.8 \mathrm{a}$ & \\
$\mathrm{T}+\mathrm{P}$ & $4.69 \mathrm{a}$ & \\
$\mathrm{T}+\mathrm{A} 1 \mathrm{~kg}+\mathrm{P}$ & $4.8 \mathrm{a}$ & \\
$\mathrm{T}+\mathrm{A} 2 \mathrm{~kg}+\mathrm{P}$ & $3.84 \mathrm{a}$ & \\
$\mathrm{T}+\mathrm{A} 3 \mathrm{~kg}+\mathrm{P}$ & $3.99 \mathrm{a}$ & \\
\hline
\end{tabular}

Hasil analisis ragam menunjukkan bahwa penambahan abu vulkanik dan pupuk kandang tidak nyata mempengaruhi berat brangkasan kering tanaman. Hasil tersebut mungkin disebabkan karena kurang optimalnya pertumbuhan tanaman kacang tanah saat fase vegetatif mengingat kondisi lingkungan tempat penelitian yang dilakukan memiliki suhu yang dan kelembapan udara relatif tinggi sehingga menyebabkan proses transpirasi berjalan cepat yang mengakibatkan cadangan air tanaman menurun. Menurut Hendriyani dan Setiani (2009), kandungan air yang menurun pada tanaman secara langsung juga akan menghambat sintesis klorofil pada daun yang dapat menyebabkan laju 
fotosintesis menurun sehingga fotosintat yang dihasilkan sedikit disamping itu kondisi tanah yang keras akibat pemberian abu kedalamnya mengakibatkan perakaran tanah tidak bisa menyerap unsur hara serta air dengan baik.

Hasil korelasi menunjukkan bahwa terdapat hubungan antara brangkasan kering tanaman dengan serapan $\mathrm{Ca}(r=0.772)$. Selain karena media yang padat, pembentukan akar tanaman menjadi terhambat mungkin dikarenakan kurangnya serapan $\mathrm{Ca}$ tanaman. Terhambatnya akar ini dapat menyebabkan berkurangnya kemampuan akar untuk menyerap air dan unsur hara dari dalam tanah. Air digunakan sebagai sumber elektron dan zat pelarut yang membawa unsur hara masuk kedalam tubuh tanaman serta mentranslokasikan fotosintat hasil fotosintesis ke bagian tanaman yang lain. Apabila jumlah air yang diserap tanaman berkurang, maka konsentrasi unsur hara yang terlarut di dalamnya bisa ikut berkurang serta proses translokasi fotosintat ke bagian tanaman yang lain juga akan terhambat. $\mathrm{Hal}$ ini menyebabkan pertumbuhan tanaman menjadi terhambat tidak terkecuali berat brangkasan kering tanaman.

\section{KESIMPULAN DAN SARAN}

\section{A. Kesimpulan}

Berdasarkan penelitian yang telah dilakukan dapat diambil kesimpulan sebagai berikut:

1. Apabila dibanding dengan tanah $6 \mathrm{~kg}$, maka pemberian abu vulkanik Kelud dan pupuk kandang tidak mampu meningkatkan $\mathrm{Ca}$ tersedia tanah namun pada pemberian abu vulkanik $2 \mathrm{~kg}+$ pupuk kandang mampu secara nyata meningkatkan $\mathrm{Ca}$ total tanah Alfisols sebesar $32.5 \%$.

2. Apabila dibanding dengan tanah $6 \mathrm{~kg}$, maka perlakuan pemberian abu vulkanik Kelud dan pupuk kandang tidak mampu meningkatkan serapan Ca tanaman kacang tanah.

3. Pemberian abu vulkanik dan pupuk kandang justru menurunkan kandungan $\mathrm{Ca}$ jaringan tanaman dan pada penambahan abu vulkanik $1 \mathrm{~kg}$, Ca jaringan akan turun sebesar $31.4 \%$ dari kandungan tanah $6 \mathrm{~kg}$.

4. Abu vulkanik yang berperan sebagai media tanah tidak mampu mendukung pertumbuhan kacang tanah.

\section{B. Saran}

Berdasarkan penelitian yang telah dilakukan maka dapat disarankan bahwa perlunya penelitian lebih lanjut tentang perbedaan jenis dan dosis pupuk kandang yang digunakan untuk mempercepat tingkat dekomposisi mineral yang terkandung pada abu vulkanik Kelud.

\section{DAFTAR PUSTAKA}

Anda, M., W., Wahdini, 2010, Sifat Komposisi Mineral dan Kandungan Berbagai Unsur pada Abu Erupsi Merapi, Oktober-November 2010, Balai Besar Penelitian dan Pengembangan Sumberdaya Lahan Pertanian.

Andreita, RR. 2011, Dampak Debu Vulkanik Gunung Sinabung Terhadap Perubahan Sifat Kimia Tanah Inceptisol, Skripsi, Medan : Departemen IImu Tanah Fakultas Pertanian Universitas Sumatera Utara.

Barber, SA. 1984, Soil Nutrient Bioavaibility, John Wiley and Son, Inc. United States of America.

Barker AV., David, J. Pilbeam, 2007, Handbook of Plant Nutrition, CRC Press, 600 Broken Sound Parkway NW, Suite 300, Boca Raton, FL 33487. 613p. ISBN: 0-8247-5904-4

Clarkson David, T. 1984, Calcium Transport Between Tissues and Its Distribution in the Plant, J Plant cell and Environment, 7(6) : 449-456, DOI: 10.111/j. 13653040.1984.tb01435.x.

Cook, RJ., JC., Barron, RI., Papendick, GJ., Williams, 1981, "Impact of Agriculture of the Mount St. Helens Eruptions", Science 211 : 16-22, Bibcode:1981Sci...211...16C, DOI:10.1126/science.211.4477.16. .

Dwidjoseputro, 1994, Pengetahuan Fisiologi Tumbuhan, Jakarta : Gramedia.

Hendriyani Ika Susanti, Nintya Setiari, 2009, Kandungan Klorofil dan Pertumbuhan Kacang Panjang (Vigna sinensis) pada Tingkat Penyediaan Air yang Berbeda, J Sains and Mat, 17(3) : 145-150.

Jordan David, L., et al. 2016, Peanut Information.Collage og Agriculture and Life Science, North Carolina State University.

Keisling, TC., ME., Walker, 2008, Calcium Absorption Efficiency of Peanut Fruit of Various Cultivars, J of Plant Nutrition, 5(2) : 91-95, DOI: 10.1080/01904168209362940.

Larcher, W., 1975, Physilogical Plant Ecology, London : University Inssbruck.

Li, R., P., Guo, M., Baum, S., Grando, S., Ceccarelli, 2006, Evaluation of Chlorophyll Content and Fluorescence Parameters as Indicators of Drought Tolerance in Barley, $\mathrm{J}$ Agricultural Sciences in China, 5(10) : 751757, DOI: 10.1016/S1671-2927(06)60120-X.

Ohorella, Z., 2011, Respon Pertumbuhan dan Produksi Tanaman Kedelai pada Sistem Olah Tanah yang Berbeda, J Agronomika, $1(2)$ : 92-98, ISSN :2088-8066. 
R., Lal, 2003, Soil Erosion Problems on Alfisols in Western Nigeria, VI. Effects of Erosion on Experimental Plots, Geoderma, 25(3-4) : 215 - 230, DOI:10.1016/00167061(81)90037-9.

Reuter, DJ., JB., Robinson, 1986, Plant Analysis, an Interpretation Manual, Melbourne, Sidney : Inkata Press.

Rosmarkam Afandhie, Yuwono NW. 2002, IlmuKesuburan Tanah, Yogyakarta : Kanisius.

Rostaman, T., Antonius, K., Linca, A. 2012, Perbaikan Sifat Tanah dengan Dosis Abu Vulkanik pada Tanah Oxisols, 357-368, dalam Wigena et al. (Eds). Prosiding Seminar Nasional Teknologi Pemupukan dan Pemulihan Lahan Terdegradasi, Bogor, 29-30 Juni 2012., Badan Penelitian dan Pengembangan Pertanian, Kementerian Pertanian.

Salisbury, FB., CW., Ross, 1995, Fisiologi Tumbuhan Jilid 1 Terjemahan Diah $R$ Lukman dan Sumaryo, Bandung : ITB.

Sitompul, SM., B., Guritno, 1995, Analisis Pertumbuhan Tanaman, Yogyakarta : Gajah Mad a University Press.

Soemarno, 2010, Manajemen Agroekosistem, Malang : Fakultas Pertanian Universitas Brawijaya.

Winarso, S. 2005, Kesuburan Tanah : Dasar Kesehatan dan Kualitas Tanah, Yogyakarta : Gava Media. 